\title{
Important Characteristics of Buddhist Monk as the Moral Teacher:
}

\author{
A Case study in Patumthani Province, Thailand
}

\author{
M. Pigultong* \\ Faculty of Technical Education \\ Rajamangala University of Technology Thanyaburi \\ Patumthani, Thailand \\ *mtpphd@rmutt.ac.th
}

\begin{abstract}
Thailand declared an educational innovation area as a new act to improve the achievement of the students that every province must drive all provincial educational organizations to support the new act. If Patumthani province has the plan to be a city of innovation soon, especially educational innovation plan, how will the Buddhist monks as the moral teacher in Patumthani province to improve the educational quality of the students and support the educational innovation area act? The temples are one of the important factors to support the educational innovation area act because there are many of the moral teachers to teach the students in each school, but they do not know about the important characteristics to support the act. There is no research about their important characteristics as the moral teacher to point the new direction to support the Thailand educational innovation area act. This research consisted of qualitative and quantitative data collection, aim to find out the important characteristics of Buddhist monks as the moral teacher to support Thailand's educational innovation area act. Several data collection methods were used for data collection. The first method is qualitative data collection, divided into 2 steps, 1) Executive in-depth interview technique with the temple administrative committee by Purposive Sampling method. 2) Participatory data collection by the researcher to be ordained as the Buddhist monk for 15 days. The second method is quantitative data collection was used in step 3; the sample is 26 Buddhist monks as the moral teacher in the temple of Patumthani province by the Purposive Sampling method. Content analysis and Exploratory Factor Analysis (EFA) were used for data interpretation. The research findings Shawn that, Buddhist monk as the moral teacher must have nine important characteristics consist of: 1) The media developer, 2) The learning environment Manager, 3) The researcher, 4) The basic educator, 5) The basic engineer, 6) The temple manager, 7) The Social counselor 8) The knowledge integrator and 9) The ICT user.
\end{abstract}

Keywords-moral teacher, Buddhist monk, moral teacher characteristics, educational innovation, participatory data collection method

\section{BACKGROUND OF THE STUDY}

Thailand declared an educational innovation area as a new act to improve the achievement of the students that every province must drive all provincial educational organizations to support the new act. This act will make freedom of educational innovation to improve the academic quality of the students by the Government, Sub-district Administrative Organization (SAO), Private companies, and social groups [1].

Patumthani province is in the North of Bangkok. There is an area 1,525.856 sq. km. There are 7 districts in Patumthani that included 186 temples [2]. The population is $1,146,092$ people, as shown in Figure 1 .

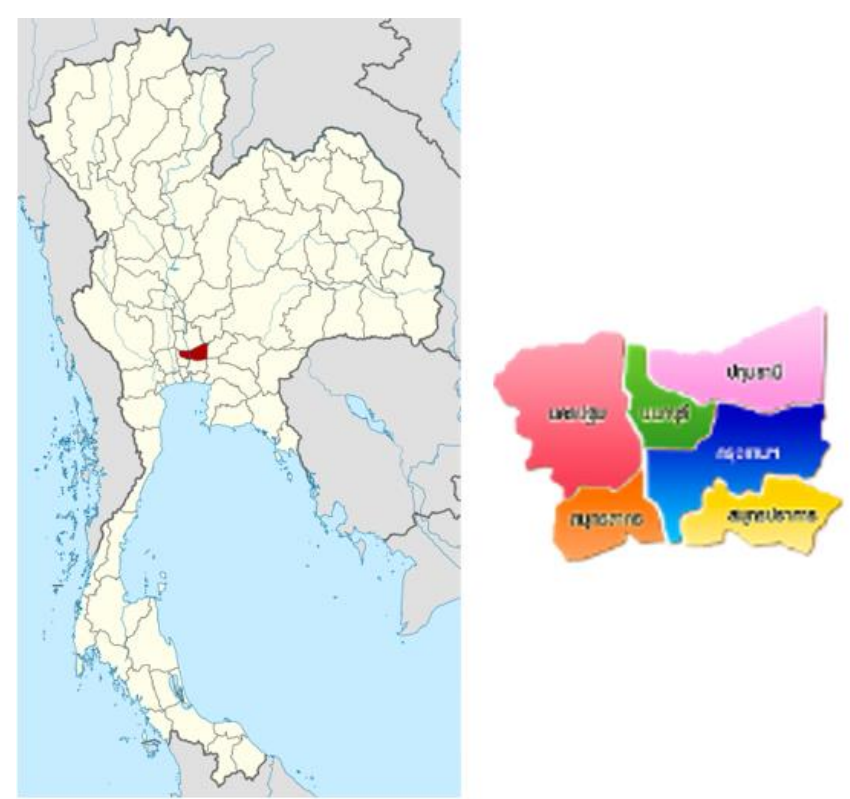

Fig. 1. Shows the area of Patumthani province

There are many provincial education organizations such as local school Moral Teacher, Buddhist Monk, Moral Teacher 
characteristics and temples to educate the people. The temples are one of the important factors to develop the students and to support Thailand's educational act because there are many of the moral teachers to teach the students in each school, but they do not know about the important characteristics.

Panyanantaram temple is one of many temples that has been to take part with Patumthani province for development to the educational innovation area because there are many of the moral teachers to teach the students in each school to support the act. It was established on May 2, 2002, and currently owns the land of 69 Rai 3 Ngan and 22 square-wa in Patumthani province. The aims to moral educate, to meditation training with various curriculums for local and nonlocal people. All and every year, there are many educational institutions, government organizations, and private agencies are submitting their members to attend the courses for developing their personality. Therefore, the Panyanantaram temple is the place there is the maximum number of Buddhist monks as the moral teacher in Patumthani province. And where is the center to teach the moral of Patumthani province.

\section{The IMPORTANCE OF BUdDHIST MONKS AS A HUMAN RESOURCE}

Thai people faithfully and praised Buddhist monks for being a valued person in society more than 2500 years ago. When Buddhism propagates to Thailand by the Buddhist monks, who have been assigned from the lord Buddha to embed in the community as a local people, they brought Buddhist philosophy, Buddhist precept, and ethics from the lord Buddha to the city for the cultivation of virtue. The Buddhist monks are associated with members of the Thai society in many different dimensions since they birth until death. No matter, people are happy or sad, the Buddhist monks will function as a counselor to bring up people's life.

\section{THE IMPORTANCE OF BUDDHISM HUMAN RESOURCES DEVELOPMENT}

As described earlier, the Buddhist monk is hopes and social psychological center. The role of Buddhist monks is strict discipline, being a solitude person, adhering to the principles of Buddhism for bringing up people living in society. Therefore, Buddhist monks must be to the development of their social mindset and change their status to live with the community and ready to lead the people to develop Thailand in the right way. [3].

Moreover, "The key role of a Buddhist monk as a representative of a load of Buddha, that they are the persons must have been kept of Buddhist continually [4]. Also, the key role of Buddhist monks is teaching morality by local people" Buddhist monks as the social leader, they must be the real good behavior leader and stand as the social counselor and must be developed in the right direction and match with Thailand development.
At present, the Buddhist monk's ability of social counselors is in various directions, up to their knowledge, experience, and learning skills. Some Buddhist monks have the teaching skills that do not relate to the principles of Buddhism and do not match with the direction of Thailand's development. Because they lack the opportunity to train the right characteristics. Therefore, if they know about their characteristics. It is an excellent way to give them to training in the right direction.

Some Buddhist monks usually sermonize Buddha's story, Buddha's words, virtues in everyday life to guide the people to get a good experience in the way of Buddhists, as shown in Figure 2.

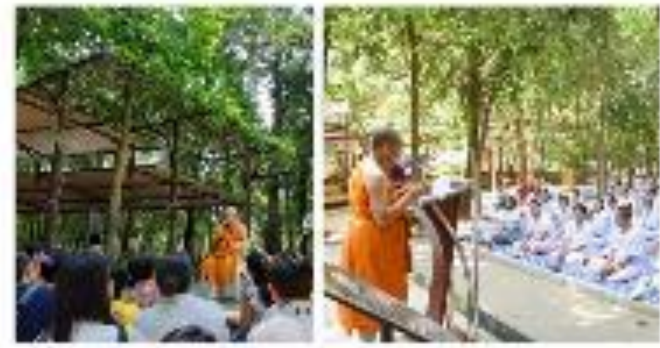

Fig. 2. Shows the monks sermonizing with the people.

Buddhist monk is the center of society. Therefore, Buddhist monks must be the participant to develop in many ways to keep the direction of Thailand's educational innovation area act.

\section{The Key PRoblems}

Even though Thai society has changed more than 2500 years. The Buddhist monks have also been regarded by Buddhists as the social leaders. However, in the case of Buddhism, many temples in Thailand as the local religious organizations are more aggressive defensive-oriented to make strong and effective Buddhism.

The key problems are 1) the Buddhist monk as the moral teacher does not know about their important characteristic 2) There is no research yet about their important characteristics as the moral teacher to point the new direction to support Thailand's educational innovation area act [5].

According to the problems, Rajamanagala University of Technology Thanyaburi is the research organization in Patumthani Province that has been the readiness to conduct the mixed-method research to find the key problems. Therefore, this research result will bring the appropriate finding to support the local religious organization as part of Patumthani Province belong to the educational innovation area.

\section{RESEARCH QUESTIONS}

- What are the important characteristics of Buddhist monks as the moral teacher to support Thailand's educational innovation area act?

- What are the sub-characteristics of each one? 


\section{THE PURPOSE OF THE STUdY}

To find out about the Buddhist monk's important characteristic as the moral teacher to support Thailand's educational innovation area act.

\section{RESEARCH METHODS}

This research consisted of qualitative and quantitative data collection were used for data collection as following proceed.

The first step is the qualitative data collection by the Executive in-depth interview technique. The population is the Panyanantaram temple administrative committee by the Purposive Sampling method. Data interpretation was used by the Content Analysis method. Data collection instruments are the Executive in-depth interview form and the photographs, as shown in Figure 3.
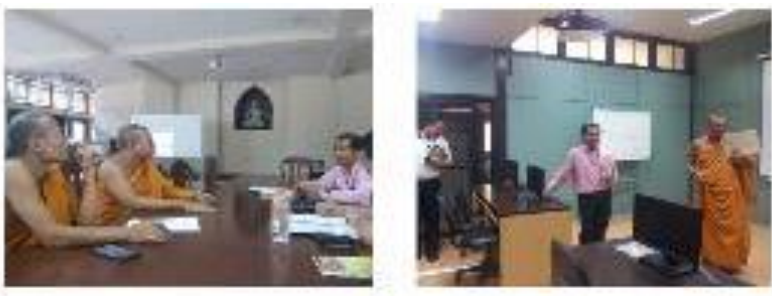

Fig. 3. Shows the Data collection with the Panyanantaram temple Administrative Committee

The second step, Participatory Data Collection method collect by the researcher to ordained as a Buddhist monk with himself at Panyanantaram temple in Patumthani province and Suandham Angthong to study the lifestyle and religious activities of Buddhists monks in 15 days. The research instrument is activities photographs, as shown in Figure 4. Data interpretation was use by Content Analysis technique.

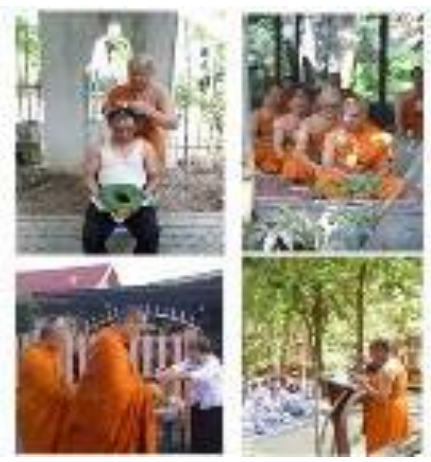

Fig. 4. Shows the Participatory Data Collection by the researcher to ordained as a Buddhist monk.

After the researcher completed collect both of 2 steps. The researchers conducted an analysis of the real data from an indepth interview with the mission of the Buddhist monks and brought the experience straight from self-aggregated data collection. Then, researchers introduced the data that was developed the closed-end query on the key features to proceed in the third step.

In the third step, Quantitative data collection, the sample group collects quantitative data from Buddhist monks, who were acting on the moral teacher in a total of 26 Buddhist monks by the Exploratory Factor Analysis method.

\section{RESEARCH FINDINGS}

The Research Findings show that the Buddhist monks as the moral teacher must have 9 important characteristics consisted of, as shown in Figure 5.

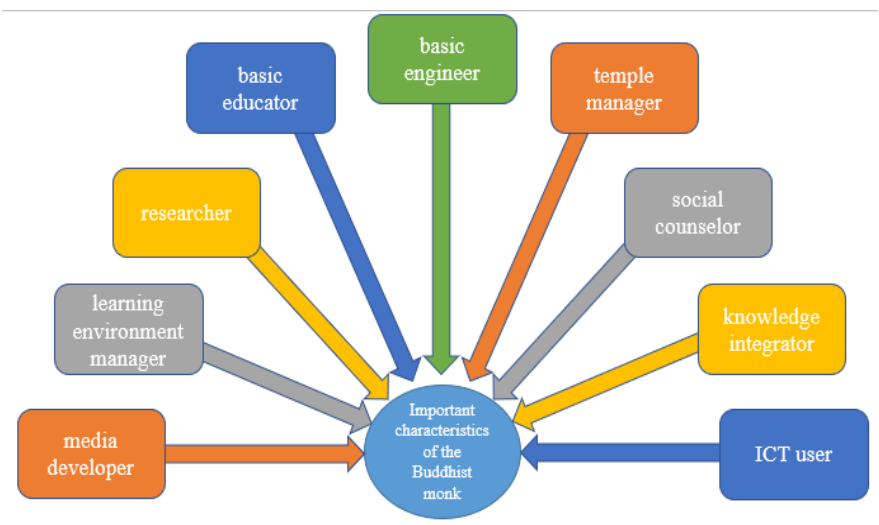

Fig. 5. Shows important characteristics of The Buddhist monk.

From Figure 5, shows that the Buddhist monks as the moral teacher must have 9 important characteristics consisted of.

- The media developer

- The learning environment manager

- The researcher

- The basic educator

- The basic engineer

- The temple manager

- The social counselor

- The knowledge integrator

- The ICT user

TABLE I. THE MEDIA DEVELOPER

\begin{tabular}{|l|l|}
\hline \multicolumn{1}{|c|}{ Eigenvalue $=17.448$} & Factor Loading \\
\hline Developing radio broadcasting Program & 0.873 \\
\hline Developing of graphic material & 0.794 \\
\hline Media and video development & 0.784 \\
\hline Augmented reality development (AR) & 0.783 \\
\hline Printing media development & 0.737 \\
\hline Photography development & 0.655 \\
\hline Computer-assisted instruction development & 0.546 \\
\hline Virtual reality development (VR) & 0.422 \\
\hline
\end{tabular}


Table 1 shows an Eigenvalue $=17.448$. In these feathers, the sample group is to focus on the development of Buddhist literacy, which is a modern medium of media. Suitable for applying to the current situation, especially for the development of audio media that can broadcasts extensively in both Online and Offline formats, it is also important to use digital technologies like Augmented Reality (A.R.) and Virtual Reality (V.R.).

TABLE II. THE LEARNING ENVIRONMENT MANAGER

\begin{tabular}{|l|l|}
\hline \multicolumn{1}{|c|}{ Eigenvalue $=4.374$} & Factor Loading \\
\hline Buddhist Learning Resource Management & 0.768 \\
\hline Research Academic reference & 0.724 \\
\hline Buddhist communication plan & 0.706 \\
\hline Excellence in conveying knowledge of Buddhism & 0.642 \\
\hline Trainer Skills & 0.635 \\
\hline Development of practical activities & 0.582 \\
\hline The environment in the propagation of Dharma & 0.485 \\
\hline
\end{tabular}

Table 2 shows an Eigenvalue $=4.374$, in this feature, the sample group is important for the management of Buddhist learning resources that can be used as a source of research. The academic reference to those who are interested, including being a Buddhist literacy speaker in a favorable environment.

TABLE III. THE RESEARCHER

\begin{tabular}{|l|l|}
\hline \multicolumn{1}{|c|}{ Eigenvalue $=2.905$} & Factor Loading \\
\hline Academic writing & 0.933 \\
\hline Access to academic publications & 0.869 \\
\hline Information Technology Skills for research & 0.643 \\
\hline Academic publishing & 0.612 \\
\hline Access to Research Data & 0.583 \\
\hline
\end{tabular}

Table 3 shows an Eigenvalue $=2.905$, in this feature. The sample is a global emphasis on the creation of knowledge and distributes at the same time, using scientific processes to collect information as research instruments.

TABLE IV. THE BASIC EDUCATOR

\begin{tabular}{|l|l|}
\hline \multicolumn{1}{|c|}{ Eigenvalue $=2.347$} & Factor Loading \\
\hline Foreign language skills & 0.823 \\
\hline General skills & 0.694 \\
\hline General Educational plan and knowledge & 0.643 \\
\hline Knowledge skills & 0.610 \\
\hline Calculation and statistics skills & 0.490 \\
\hline Relaxation Skills for the meditation & 0.450 \\
\hline
\end{tabular}

Table 4 shows an Eigenvalue $=2.347$, in this feature. The results show that the sample group has enough knowledge to provide consultation or disseminate their basic knowledge in communicating with foreigners or learning the language skills of foreign documents. Protection of property in religious places useful travel also, knowledge is applied to community practices in need.
TABLE V. THE BASIC ENGINEER

\begin{tabular}{|l|l|}
\hline \multicolumn{1}{|c|}{ Eigenvalue $=\mathbf{1 . 8 8 1}$} & Factor Loading \\
\hline Electrical system Maintenance & 0.844 \\
\hline Electrical appliances maintenance & 0.696 \\
\hline Mechanical maintenance & 0.686 \\
\hline Water supply system Maintenance & 0.634 \\
\hline
\end{tabular}

Table 5 shows an Eigenvalue $=1.881$. Also, the samples focus on the maintenance of various public infrastructures in the temple.

TABLE VI. THE TEMPLE MANAGER

\begin{tabular}{|l|l|}
\hline \multicolumn{1}{|c|}{ Eigenvalue $=1.388$} & Factor Loading \\
\hline Financial budget management & 0.718 \\
\hline Management leadership & 0.716 \\
\hline Marketing Principles & 0.673 \\
\hline Property management in religious places & 0.563 \\
\hline
\end{tabular}

Table 6 shows an Eigenvalue $=1.388$. The results show the importance of managerial skills in the temple as it is a social organization that is gathered from several parties, such as a Buddhist monk, a group of representatives, as well as the rules. The rules are used as a tool to maintain the entire budget, personnel, resources, and community-related activities.

TABLE VII. THE SOCIAL COUNSELOR

\begin{tabular}{|l|l|}
\hline \multicolumn{1}{|c|}{ Eigenvalue $=1.335$} & Factor Loading \\
\hline Modern accumulated skills & 0.867 \\
\hline Psychology and counseling to the meditation & 0.705 \\
\hline
\end{tabular}

Table 7 shows an Eigenvalue $=1.335$. In this feature, a sample group takes emphasis on people in the community who want to consolable persons on various issues to use the right method, such as counseling techniques, practice, guidance, wisdom, etc.

TABLE VIII. THE KNOWLEDGE INTEGRATOR

\begin{tabular}{|l|l|}
\hline \multicolumn{1}{|c|}{ Eigenvalue $=1.086$} & Factor Loading \\
\hline Religious integration & 0.749 \\
\hline $\begin{array}{l}\text { Participation in the development of higher education } \\
\text { courses }\end{array}$ & 0.449 \\
\hline
\end{tabular}

Table 8 shows an Eigenvalue $=1.086$. The subjects featured on the knowledge that is scattered at various sources, which may be the preaching of Buddha. It could be the teachings of other religions, which can be blended with the aim of training.

TABLE IX. THE ICT USER

\begin{tabular}{|l|l|}
\hline \multicolumn{1}{|c|}{ Eigenvalue $=1.069$} & Factor Loading \\
\hline The use of digital technology to dissemination. & 0.654 \\
\hline Using a ready-to-use program for the ministry & 0.598 \\
\hline
\end{tabular}

Table 9 shows an Eigenvalue $=1.069$. In this feature, the sample provides a focus on having the skills to use of digital 
technology for religious cognitive dissemination, as well as the use of digital technology tools to enhance the efficiency and effectiveness to manage the temple and conduct their teaching.

\section{CONCLUSION}

The Buddhist monks as the moral teacher must have 9 important characteristics consisted of; 1) The media developer shows an Eigenvalue $=17.448$. In these feathers, the sample group is to focus on the development of Buddhist literacy, which is a modern medium of media. Suitable for applying to the current situation, especially for the development of audio media that can broadcasts extensively in both of Online and Offline formats, it is also important to use digital technologies like Augmented Realty (AR) and Virtual Reality (VR). 2) The learning environment manager shows an Eigenvalue $=$ 4.374. In this feature, the sample group is important for the management of Buddhist learning resources that can be used as a source of research. The academic reference to those who are interested, including being a Buddhist literacy speaker in a favorable environment, and has a straightforward plot of Buddhism. 3) The researcher shows an Eigenvalue $=2.905$ in this feature. The sample is a global emphasis on the creation of knowledge that is secular, coupled with distributes, using scientific processes to collect information as research tools. 4) The basic educator shows an Eigenvalue $=2.347$ in this feature. The results show that the sample group has enough knowledge to provide consultation or disseminate their basic knowledge. In communicating with foreigners or learning the language skills of foreign documents. Protection of property in religious places useful travel in addition, learning is applied to community practices in need. 5) The basic engineer shows an Eigenvalue $=1.881$. In addition, the government should pay attention to the state of religious property through the maintenance of various public infrastructures. 6) The temple manager shows an Eigenvalue $=1.388$. The results show the importance of managerial skills in religious institutions as it is a social organization that is gathered from several parties, such as a Buddhist monk, a group of representatives, as well as the rules. The rules are used as a tool to support the entire budget, personnel, resources, and community-related activities. 7) The social counselor shows an Eigenvalue $=1.335$. In this feature, a sample group takes emphasis on people in the community who want to counsel on various issues where the Buddhist monks need to assist. The solution is to provide a solution that is especially wise to use the right method for the day as a healing tool such as counseling techniques, practice, guidance, wisdom, etc. 8) The knowledge integrator shows an Eigenvalue $=1.086$. The subjects featured on the knowledge that is scattered at various sources, which may be the preaching of Buddha. It could be the teachings of other religions, which can be blended with the aim of training. 9) The ICT user shows an Eigenvalue $=1.069$. In this feature, the sample provides a focus on having the skills to use of digital technology for religious cognitive dissemination, as well as the use of digital technology tools to enhance the efficiency and effectiveness to manage the temple and conduct their teaching.

\section{FURTHER RESEARCH}

The researcher recommends that the results of this research be carried out as follows: 1) Develop training courses according to the appropriate characteristics 2) Expand the research results to other provinces and 3) Research for affiliate development.

A network of cooperation between local educational organizations and religious organizations develops Buddhist monks' desirable attributes as the moral teacher appropriately.

\section{ACKNOWLEDGMENT}

This research was supported by the Faculty of Technical Education, Rajamangala University of Technology Thanyaburi.

\section{REFERENCES}

[1] Royal Thai Government Gazette, 2019. [Online]. Retrieved from: http://www.ratchakitcha.soc.go.th/DATA/PDF/2562/A/056/T_0102.PDF

[2] Wikipedia, "Pathum Thani Province," 2020. [Online]. Retrieved from: https://en.wikipedia.org/wiki/Pathum_Thani_Province

[3] PhraRatchaSutthiyanaMangkala, "Roles of monks in Thai society," 2020. [Online]. Retrieved from: http://www.mongkoltemple.com/page02/articles017.html

[4] N. Sangklinhom, "Duties of monks," 2020. [Online]. Retrieved from: https://sites.google.com/site/nathphngssangkhklinhxmiom/hnathi-khxngphra-sngkh

[5] S. Ao-aramrusmi, S. Kanto, and P. Maha kraiwan, "Strategy for Buddhism Propagation the National Office of Buddhism in the next Decade (2016 - 2025 A.D.)," Mahamakut Graduate School Journal, vol. 17, no. 1, pp 1- 13, 2019. 